\title{
Sex, Genes, and Traumatic Brain Injury (TBI): A Call for a Gender Inclusive Approach to the Study of $\mathrm{TBI}$ in the Lab
}

\author{
Kelli A. Duncan ${ }^{1,2 *}$ and Sarah Garijo-Garde ${ }^{2}$ \\ ${ }^{1}$ Department of Biology, Vassar College, Poughkeepsie, NY, United States, ${ }^{2}$ Program in Neuroscience and Behavior, Vassar \\ College, Poughkeepsie, NY, United States
}

Keywords: TBI, transgender, gender, sex differences, hormones

\section{INTRODUCTION}

OPEN ACCESS

Edited by:

Rosa Fernández,

University of A Coruña CICA-INIBIC

Strategic Group, Spain

Reviewed by:

Alexandre González-Rodríguez,

Parc Taulí Foundation, Spain

Ashlyn Swift-Gallant,

Memorial University of

Newfoundland, Canada

*Correspondence:

Kelli A. Duncan

keduncan@vassar.edu

Specialty section:

This article was submitted to

Neuroendocrine Science,

a section of the journal

Frontiers in Neuroscience

Received: 16 March 2021

Accepted: 12 April 2021

Published: 05 May 2021

Citation:

Duncan KA and Garijo-Garde S (2021)

Sex, Genes, and Traumatic Brain

Injury (TBI): A Call for a Gender

Inclusive Approach to the Study of TBI

in the Lab.

Front. Neurosci. 15:681599.

doi: 10.3389/fnins.2021.681599
Traumatic Brain Injury (TBI) is a leading cause of morbidity and moribundity in the United States (Bruns and Hauser, 2003; Corrigan et al., 2010). A number of factors including sex influence TBI clinical outcome. Both clinical and lab studies show a clear influence of sex on TBI outcome. However, whether this is mediated by hormones, genes, or both is still under debate (Gupte et al., 2019; Ma et al., 2019; Mikolić et al., 2020). The majority of research focuses on factors of endogenous hormone signaling (release and reception) in natal males (Slewa-Younan et al., 2004; Dubal et al., 2006; Herson et al., 2009; Griesbach et al., 2015; Clevenger et al., 2018; Mollayeva et al., 2018; Späni et al., 2018; Ma et al., 2019). This excludes natal females and both males and females taking exogenous hormones for hormone replacement (HRT) or cross sex hormone therapy (CSHT) as part of a gender confirming therapy (Mollayeva et al., 2018; Späni et al., 2018; Ma et al., 2019; Giordano et al., 2020; Biegon, 2021). While transgender and gender non-conforming (TGNC) individuals make up $0.3-0.5 \%$ of the global population, they are affected by violence at higher rates compared to cisgender individuals (Jauk, 2013). Despite these higher rates of violence and increased risk of TBI, the TGNC population remains understudied in the TBI field (Safer et al., 2016). This bias extends to healthcare settings where many TGNC individuals face significant barriers to obtaining high-quality, compassionate medical care at primary care facilities, especially in emergency rooms, where most TBIs are diagnosed (Sanchez et al., 2009; Porter et al., 2016; Reisner et al., 2016; Safer et al., 2016; Dickey and Singh, 2017).

Research regarding transgender health has dramatically increased, yet there is still significant room for improvement as TGNC individuals are at an increased risk for several health issues (Reisner et al., 2016; Ackerley et al., 2019; Neblett and Hipp, 2019; Yeung et al., 2019; Wiepjes et al., 2020). A gender inclusive approach in biomedical research is vital to our understanding and treatment of TBI. The aim of this paper is to call upon lab-based investigators to approach the study of TBI and also biomedical research in a gender inclusive manner.

\section{SEX, GENDER, AND TBI: BEYOND THE BINARY}

TBI has a biphasic response. While the primary insult is often short in duration, the secondary phase can linger for hours to weeks after the initial injury. Like the primary injury, if untreated, 
this secondary phase can lead to a manifestation of clinical or behavioral symptoms, including death (Lenzlinger et al., 2001; Bramlett and Dietrich, 2007; Maas et al., 2008). The majority of research focuses on both decreasing the chance of injury and decreasing the secondary effects of that injury (Fitch et al., 1999; Day et al., 2013; Kim et al., 2015; Ripley et al., 2020; BourgeoisTardif et al., 2021). Severe symptoms include long-term cognitive or behavioral deficits, while moderate to mild symptoms include headaches, dizziness, nausea, and short-term amnesia (Prins et al., 2013). Additionally, if untreated, these long-term effects of TBI can result in increased risk of neurodegenerative diseases such as Alzheimer's disease, chronic traumatic encephalopathy, and Parkinson's disease (Lye and Shores, 2000; McKee et al., 2009; Hutson et al., 2011). Treatment of secondary injuries is complex, as there are a multitude of neurobiochemical and metabolic pathways that are activated across multiple time scales and can differ depending on sex (Prins et al., 2013; Saldanha et al., 2013; Rahimian et al., 2019; Mikolić et al., 2020).

Hormone production or availability likely contribute to TBI outcome which results in females largely being reported to be more resilient than their male counterparts (Mollayeva et al., 2018; Ma et al., 2019; Rubin and Lipton, 2019). Furthermore, when comparing prepubescent, premenopausal, and post-menopausal women, premenopausal, and pubescent females generally have lower rates of mortality and better prognoses than older, premenopausal adults (Du et al., 2004; Ley et al., 2013; Albrecht et al., 2016; Ranganathan et al., 2016; Ma et al., 2019). These conclusions are supported by studies directly examining the role of estrogens, progesterone, androgens, and their metabolites following TBI. The studies have identified these steroids via activation of their receptors (which can vary by sex following injury) as being neuroprotective by preventing the brain from edema, necrosis, apoptosis, and inflammation (Stein and Hoffman, 2003; Bryant et al., 2006; Dubal et al., 2006; Spence and Voskuhl, 2012; Acaz-Fonseca et al., 2016; Brotfain et al., 2016; Duncan and Saldanha, 2020). These effects can occur acutely after the injury, but can have prolonged effects lasting weeks after the initial injury (Suzuki et al., 2007). However, the majority of these studies have focused on endogenous release vs. exogenous therapy and when comparing humans to lab models, we can see the opposite result (Hall et al., 2005; Stein, 2015; Gupte et al., 2019).

\section{How to Study TBI Through a Transgender Lens?}

The process of transitioning is complex and can be heavily individualized, which partially explains some of the difficulties in developing a lab-based model. Despite the limited information regarding the development of human gender identity, there has been significant progress in using animal models to demonstrate the neurodevelopment pathways leading to sex differences in brain and behavior (Joel and McCarthy, 2017; Choleris et al., 2018; Theisen et al., 2019). From these studies, three main factors: environment, genes, and hormones, have all been identified as mechanisms key to understanding human gender identity.
Environment (social or physical) plays a major role in the development of human gender including transgender identity by directly or indirectly (epigenetics) altering gene expression and behavior (Szyf et al., 2008; Arnold, 2017). However, the role of the environment is difficult to model in non-human subjects; and therefore, we will focus primarily on the other two factors identified (genes and hormones).

\section{Factors Affecting TBI Outcome in TGNC Populations \\ Genes}

A number of studies have suggested a genetic contribution to the development of transgender identity (Lippa and Hershberger, 1999; Bentz et al., 2007, 2008; Fernández et al., 2015; Smith et al., 2015; Fisher et al., 2018; Polderman et al., 2018; Foreman et al., 2019). Specifically, twin studies have found heritability anywhere between $38-47 \%$ in adolescent natal females and $25-43 \%$ in adolescent natal males, while these numbers decrease to 11$44 \%$ and $27-47 \%$ in adults (Fisher et al., 2018; Polderman et al., 2018; Theisen et al., 2019). A number of genes were identified from these studies, many of which were also previously identified in studies of sexual differentiation in animal models. These include COMT, PIK3CA, RYR3, SRD5A2, STS, and SULT2A1, as well as variants of genes coding aromatase, androgen receptor (AR), estrogen receptors (ER) $\alpha \& \beta$, and $17 \alpha$-hydroxylase (Fernández et al., 2015, 2018; Smith et al., 2015; Yang et al., 2017; Fisher et al., 2018; Foreman et al., 2019; Theisen et al., 2019). In terms of sex differences in TBI, we have also identified differences in a number of these genes as well, including PIK3C, SULT2A1, aromatase, AR and ERs, and 17 hydroxylase (GarciaSegura et al., 2003; Duncan and Saldanha, 2011, 2013; Saldanha et al., 2013; Pedersen et al., 2018; Cook et al., 2020; Duncan, 2020). Suggesting that these genes may have variations in their response following TBI and can serve as first candidates for examining differences in gene expression. For example, ER $\alpha$ mediates the estrogenic neuroprotective effects of TBI (Dubal et al., 2006; Duncan and Saldanha, 2020) and TGNC individuals have differences in constitutive receptor expression or different polymorphisms that may affect their ability to activate these neuroprotective pathways (Fernández et al., 2018). Discerning how these receptors and genes may change in TGNC individuals is key to our understanding of their activation following TBI.

Furthermore, the use of the four core genotype mouse model which uncouples chromosomal (X, Y) effects from gonadal influence along with the $\mathrm{XY}^{*}$ mice could be a powerful tool in determining the chromosomal/genetic contributions during TBI (Arnold and Chen, 2009; Corre et al., 2016; Arnold, 2020). Comparison of $\mathrm{XX}$ and $\mathrm{XY}$ mice with the same type of gonads, but different sex chromosomes can help in determining the role of sex linked genes vs. hormone availability. While not fully a model for TGNC populations, this is a powerful tool for determining the relative contribution of a sex difference. Currently, two studies have examined TBI using one of these models and found that in young animals, hormones and not chromosomes shaped response; however, this was reversed in aged populations (Manwani et al., 2015; McCullough et al., 2016). 
More work is on-going to determine the differences in gene expression following TBI, and if these differences are the same between cis and transgender individuals. The use of these two powerful models can help to determine if a sex difference in TBI are mediated by chromosomes, hormones, or both, especially when paired with cross hormone therapies.

\section{Hormones}

Steroid hormone levels and receptors are markedly different in natal males and females throughout most of their lifespan and clearly play a role following TBIs (Arnold, 2017; Gölz et al., 2019; Giordano et al., 2020). In terms of TGNC individuals, life-long hormonal therapy is often a key component of their transition and can be implemented as early as adolescence (Deutsch et al., 2015; Hembree et al., 2017; Nguyen et al., 2018; T'Sjoen et al., 2019). One major issue with studying individuals that are currently transitioning or have transitioned is identifying the specific medical plan used to transition. A number of various plans are used (Table 1), for both medical and personal reasons, and thus modeling can become difficult to mimic exactly (Feldman and Safer, 2009; Hembree et al., 2009; The World Professional Association for Transgender Health, 2012; American Psychological Association, 2015; Unger, 2016; Funabashi et al., 2018; Defreyne and T'Sjoen, 2019; Hamidi and Davidge-Pitts, 2019). It is important to note that many of the hormones used for transitioning differ to what are commonly used in the lab, specifically in terms of long-term use and "stacking" of multiple drugs. What we currently know about exogenous hormones and neural damage and recovery comes from teasing out the various contributions of a transition plan, but more research is needed to combine all of these components into a comprehensive model of a transitioning or transitioned individual.

\section{Trans-masculine}

TBI has historically been viewed as a problem that predominantly affects natal males, as they are both more likely to receive TBIs and have less of the circulating neuroprotective steroids: estrogen and progesterone (Späni et al., 2018; Gupte et al., 2019; Rubin and Lipton, 2019; Mikolić et al., 2020). When comparing agematched natal males and females, younger females appear to be protected against neuronal damage, suggesting that androgens may not be advantageous following injury (Dubal and Wise, 2002; Gupte et al., 2019). However, this is complicated by research that shows that males with lower testosterone have worse clinical outcomes than males within normal ranges, suggesting that while testosterone isn't detrimental in males, that other steroids may be more beneficial. This is supported by studies of natal males given testosterone for myelin repair for relapsingremitting Multiple Sclerosis that show a significant increase in neuroprotection over controls (Kurth et al., 2014). More research is necessary to further identify the role of testosterone following TBI.

In trans-masculine procedures, hormone therapy is sometimes paired with removal of the uterus and ovaries (hysterectomy and oophorectomy) via gender confirmation surgery (Coleman et al., 2012; American Psychological Association, 2015). Ovary removal has profound effects on both circulating hormone levels and TBI outcome. Cisgender women undergoing oophorectomy show lower levels of estrogen than age-matched women experiencing natural menopause (Korse et al., 2009; Perera et al., 2013; Orozco et al., 2014). Post-menopausal cisgender women, characterized by decreased circulating estrogens and progestins, show worse outcomes than premenopausal females, but better than agematched natal males (Niemeier et al., 2013). This suggests that removing circulating hormones affects TBI severity and

TABLE 1 | Drugs used for gender affirming hormonal treatments in TGNC individuals.

\begin{tabular}{|c|c|c|c|c|c|}
\hline & Drug & Common drug name(s) & $\begin{array}{l}\text { Route of } \\
\text { administration }\end{array}$ & $\begin{array}{l}\text { Proposed dosage with } \\
\text { frequency }\end{array}$ & $\begin{array}{l}\text { Blood levels (in } \\
\text { humans) }\end{array}$ \\
\hline \multirow[t]{2}{*}{$\begin{array}{l}\text { Trans-masculine } \\
\text { (FtM) }\end{array}$} & $\begin{array}{l}\text { Testosterone Undecanoate } \\
(\mathrm{UK}) \text { or Testosterone } \\
\text { Enanthate (US) or } \\
\text { Testosterone cypionate (US) }\end{array}$ & $\begin{array}{l}\text { - } \text { Andriol }{ }^{\circledR} \\
\text { - } \text { Delatestryl }^{\circledR} \\
\text { - } \text { Depo }^{\circledR} \text {-Testosterone } \\
\text { - } \text { Aveed }^{\circledR} \\
\text { - } \text { Androgel }^{\circledR}, \text { Androderm }^{\circledR}\end{array}$ & $\begin{array}{l}\text { Oral, Subcutaneous, } \\
\text { Intramuscular, } \\
\text { Transdermal }\end{array}$ & $\begin{array}{l}\text { - Undecanoate: 160-240 } \\
\text { mg/day } \\
\text { - Enanthate, cypionate: } \\
\text { 20-100 mg/week } \\
\text { - Transdermal: } \\
\text { 2.5-10 mg/day }\end{array}$ & $\begin{array}{l}\text { Testosterone: } \\
\text { 300-1,000 ng/dL }\end{array}$ \\
\hline & Progesterone (optional) & - Provera $^{\circledR}$ & Oral & • 12.5 mg/daily & \\
\hline \multirow[t]{2}{*}{$\begin{array}{l}\text { Trans-feminine } \\
\text { (MtF) }\end{array}$} & $\begin{array}{l}\text { Estradiol or Estradiol } \\
\text { valerate or Estradiol } \\
\text { cypionate }\end{array}$ & $\begin{array}{l}\text { - } \text { Depo }^{\circledR} \text {-Estradiol, } \\
\text { Depofemin }{ }^{\circledR}, \text { Estradep }{ }^{\circledR} \\
\text { - } \text { Delestrogen }^{\circledR}, \text { Progynon } \\
\text { Depot }{ }^{\circledR}, \text { Progynova }^{\circledR}\end{array}$ & $\begin{array}{l}\text { Oral, Subcutaneous, } \\
\text { Intramuscular, } \\
\text { Transdermal }\end{array}$ & $\begin{array}{l}\text { - Estradiol: 2-6 mg daily } \\
\text { - Estradiol valerate: } 2-20 \\
\text { mg/2weeks } \\
\text { - Estradiol transdermal: } \\
\text { 0.025-0.2 mg/daily }\end{array}$ & $\begin{array}{l}\text { Estrogen: 100-200 } \\
\mathrm{pg} / \mathrm{mL}\end{array}$ \\
\hline & $\begin{array}{l}\text { Anti-Androgens: Progesterone } \\
\text { Spironolactone } \\
\text { Histrelin implant }\end{array}$ & $\begin{array}{l}\text { - } \text { Provera }^{\circledR} \\
\text { - } \text { CaroSpir }^{\circledR}, \text { Aldactone }^{\circledR} \\
\text { - } \text { Vantas }^{\circledR}, \text { Supprelin LA }{ }^{\circledR}\end{array}$ & Oral, implant & $\begin{array}{l}\text { - Progesterone: 25-50 mg } \\
\text { PO daily } \\
\text { - Spironolactone: } \\
\text { 100-300 mg PO daily } \\
\text { - Histrelin: } 3.75 \text { mg monthly }\end{array}$ & $\begin{array}{l}\text { Testosterone: }<50 \\
\mathrm{ng} / \mathrm{dL}\end{array}$ \\
\hline Puberty blockers & $\begin{array}{l}\text { GnRH analogs/agonists: } \\
\text { Leuprolide acetate Histrelin }\end{array}$ & $\begin{array}{l}\text { - Lupron Depot }{ }^{\circledR} \\
\text { - } \text { Vantas }^{\circledR} \text {, Supprelin LA }\end{array}$ & $\begin{array}{l}\text { Subcutaneous, } \\
\text { Intramuscular, } \\
\text { Implanted pellet }\end{array}$ & $\begin{array}{l}\text { - Lupron Depot: } 7.5 \\
\text { mg/monthly } \\
\text { - Histrelin: } 3.75 \text { mg monthly }\end{array}$ & $\begin{array}{l}\text { Peak } \mathrm{LH}<4 \mathrm{mlU} / \mathrm{mL} \\
\text { after GnRHa } \\
\text { stimulation. }\end{array}$ \\
\hline
\end{tabular}


could potentially make FTM individuals more susceptible to neurodegeneration. Furthermore, when studying risk of neural damage, epidemiological evidence clearly shows that sex and estrogen levels are important factors in long-term outcome (Rocca, 2017; Bazzigaluppi et al., 2018). Studies of ovariectomy prior to TBI in rats showed larger areas of damage compared to intact females and thus worse outcomes (Bramlett and Dietrich, 2001). Together, these data suggest that although steroid hormones may be protective, their sudden withdrawal either before or after injury may be a key factor contributing to worse outcomes in individuals assigned female at birth (Wunderle et al., 2014). Put together, these data suggest that transgender males that elect for gender affirmation surgeries may be more susceptible to negative outcomes of TBI. However, more research is needed to understand how this can be alleviated.

\section{Trans-feminine}

If natal females are indeed better protected from TBI, then individuals undergoing trans-feminine transition may see better outcomes following hormonal transition as they typically take exogenous estrogen and progesterone, as well as anti-androgens. Typically, younger-aged cisgender women appear to be protected against neuronal damage, compared with cisgender men, but lose this advantage in their post-menopausal years (Niemeier et al., 2013; Ranganathan et al., 2016). A typical cycling female shows monthly variation in both estrogen and progesterone signaling. By using this natural variation in estrogen and progesterone response, we have been able to identify the relative contribution of estrogen and progesterone following TBI. Cisgender women in the luteal phase of their menstrual cycle, in which progesterone is highest, had worse outcomes than those in the follicular phase, in which progesterone is initially low and can therefore not decrease significantly (Wunderle et al., 2014). However, exogenous progestin use from oral contraceptives leads to better outcomes than controls in individuals assigned female at birth (Wunderle et al., 2014). The potential use of steroids in natal men following TBI has led to mixed results [see Späni et al. (Späni et al., 2018) for review]. For estrogens, the negative effects (cardiovascular disease and breast cancer) associated with shortterm or long-term use overshadow any potential neuroprotective effects (Späni et al., 2018). Progesterone, however, has been included as a treatment option in two large Phase III trials [ProTECT and SYNAPSE (Wright et al., 2007; Stein, 2015)]. Results from these two trials were not conclusive as some saw no difference in cisgender males, while a small subset saw a slight improvement in them (Lu et al., 2016; Späni et al., 2018). Specifically, sex and hormones present at the time of injury were cited as factors that mediated the effectiveness of estrogens and progesterone following injury (Stein, 2015; Stein et al., 2016; Späni et al., 2018).

Individuals undergoing trans-feminine gender affirming surgeries sometimes remove the testes, a significant source of testosterone (Coleman et al., 2012; American Psychological
Association, 2015). Paired with antiandrogen hormonal treatments, this significantly removes the amount of androgens in circulation. Therefore, one would assume that these individuals would show better responses to TBI than transgender men. However, inherent differences in gene expression in neuroinflammatory pathways or vasculature could lead to differences in response to TBI.

The bulk of research into hormone use following TBI has been done in adult or possibly aged populations. However, a significant number of individuals begin this sort of transition in early adulthood or adolescence (Smith et al., 2001; Menvielle and Gomez-Lobo, 2011; Olson, 2016). Currently, there is relatively little research on the role of cross sex hormone therapies in younger populations and nothing known about this topic in TBI research. TBI is the leading cause of death and disability in children (Ley et al., 2013; Araki et al., 2017), and children and adolescents diagnosed with a TBI are at higher risk of being diagnosed with a central endocrinopathy (Ortiz et al., 2020). These TBI induced differences in endocrine function are varied, but have been known to increase disturbances in puberty (Auble et al., 2014). To date, no studies have examined how use of CSHT could affect these pediatric outcomes and or recovery from TBI specifically.

\section{DISCUSSION}

Although we have placed a great emphasis on the lack of research in TGNC individuals, sex/gender as a biological variable is underrepresented in TBI research and requires further analysis. The increase in the number of individuals undergoing hormonal or surgical treatment to aid in gender transition calls for a substantial increase in TBI research in these underserved and marginalized populations. There is a need for evidence-based guidelines, common hormone plans, and clinically translatable diagnostic and prognostic models. Furthermore, expanding our knowledge of how exogenous hormone use affects TBI could have profound effects not only on TGNC populations, but also cisgender males and females. Such work and studies will not only help to develop better treatment options for those identifying as TGNC, but will also create a conceptual framework which can be used to extrapolate to others undergoing hormone replacement or depletion in the future.

\section{AUTHOR CONTRIBUTIONS}

KD and SG-G contributed equally the development and authoring of this manuscript.

\section{FUNDING}

This work was supported by the Vassar College Undergraduate Research Summer Institute to SG-G and Vassar College Jipson Fund to KD. 


\section{REFERENCES}

Acaz-Fonseca, E., Avila-Rodriguez, M., Garcia-Segura, L. M., and Barreto, G. E. (2016). Regulation of astroglia by gonadal steroid hormones under physiological and pathological conditions. Prog. Neurobiol. 144, 5-26. doi: 10.1016/j.pneurobio.2016.06.002

Ackerley, C. G., Poteat, T., and Kelley, C. F. (2019). Human immunodeficiency virus in transgender persons. Endocrinol. Metab. Clin. North Am. 48, 453-464. doi: 10.1016/j.ecl.2019.02.007

Albrecht, J. S., McCunn, M., Stein, D. M., Simoni-Wastila, L., and Smith, G. S. (2016). Sex differences in mortality following isolated traumatic brain injury among older adults. J. Trauma Acute Care Surg. 81, 486-492. doi: $10.1097 /$ TA. 0000000000001118

American Psychological Association (2015). Guidelines for psychological practice with transgender and gender nonconforming people. Am. Psychol. 70, 832-864. doi: $10.1037 / \mathrm{a} 0039906$

Araki, T., Yokota, H., and Morita, A. (2017). Pediatric traumatic brain injury: characteristic features, diagnosis, and management. Neurol. Med. Chir. 57, 82-93. doi: 10.2176/nmc.ra.2016-0191

Arnold, A. P. (2017). A general theory of sexual differentiation. J. Neurosci. Res. 95, 291-300. doi: 10.1002/jnr.23884

Arnold, A. P. (2020). Four core genotypes and $\mathrm{XY}^{*}$ mouse models: update on impact on SABV research. Neurosci. Biobehav. Rev. 119, 1-8. doi: 10.1016/j.neubiorev.2020.09.021

Arnold, A. P., and Chen, X. (2009). What does the "four core genotypes" mouse model tell us about sex differences in the brain and other tissues? Front. Neuroendocrinol. 30, 1-9. doi: 10.1016/j.yfrne.2008.11.001

Auble, B. A., Bollepalli, S., Makoroff, K., Weis, T., Khoury, J., Colliers, T., et al. (2014). Hypopituitarism in pediatric survivors of inflicted traumatic brain injury. J. Neurotrauma 31, 321-326. doi: 10.1089/neu.2013.2916

Bazzigaluppi, P., Adams, C., Koletar, M. M., Dorr, A., Pikula, A., Carlen, P. L., et al. (2018). Oophorectomy reduces estradiol levels and long-term spontaneous neurovascular recovery in a female rat model of focal ischemic stroke. Front. Mol. Neurosci. 11:338. doi: 10.3389/fnmol.2018.00338

Bentz, E. K., Hefler, L. A., Kaufmann, U., Huber, J. C., Kolbus, A., and Tempfer, C. B. (2008). A polymorphism of the CYP17 gene related to sex steroid metabolism is associated with female-to-male but not male-to-female transsexualism. Fertil. Steril. 90, 56-59. doi: 10.1016/j.fertnstert.2007.05.056

Bentz, E. K., Schneeberger, C., Hefler, L. A., Van Trotsenburg, M., Kaufmann, U., Huber, J. C., et al. (2007). A common polymorphism of the SRD5A2 gene and transsexualism. Reprod. Sci. 14, 705-709. doi: 10.1177/1933719107306230

Biegon, A. (2021). Considering biological sex in traumatic brain injury. Front. Neurol. 12:576366. doi: 10.3389/fneur.2021.576366

Bourgeois-Tardif, S., De Beaumont, L., Rivera, J. C., Chemtob, S., and Weil, A. G. (2021). Role of innate inflammation in traumatic brain injury. Neurol. Sci. 42, 1287-1299. doi: 10.1007/s10072-020-05002-3

Bramlett, H. M., and Dietrich, W. D. (2001). Neuropathological protection after traumatic brain injury in intact female rats versus males or ovariectomized females. J. Neurotrauma 18, 891-900. doi: 10.1089/089771501750451811

Bramlett, H. M., and Dietrich, W. D. (2007). Progressive damage after brain and spinal cord injury: pathomechanisms and treatment strategies. Prog. Brain Res. 161, 125-141. doi: 10.1016/S0079-6123(06)61009-1

Brotfain, E., E. Gruenbaum, S., Boyko, M., Kutz, R., Zlotnik, A., and Klein, M. (2016). Neuroprotection by estrogen and progesterone in traumatic brain injury and spinal cord injury. Curr. Neuropharmacol. 14, 641-653. doi: $10.2174 / 1570159$ X14666160309123554

Bruns, J., and Hauser, W. A. (2003). The epidemiology of traumatic brain injury: a review. Epilepsia 44, 2-10. doi: 10.1046/j.1528-1157.44.s10.3.x

Bryant, D. N., Sheldahl, L. C., Marriott, L. K., Shapiro, R. A., and Dorsa, D. M. (2006). Multiple pathways transmit neuroprotective effects of gonadal steroids. Endocrine 29, 199-207. doi: 10.1385/ENDO:29:2:199

Choleris, E., Galea, L. A. M., Sohrabji, F., and Frick, K. M. (2018). Sex differences in the brain: implications for behavioral and biomedical research. Neurosci. Biobehav. Rev. 85, 126-145. doi: 10.1016/j.neubiorev.2017.07.005

Clevenger, A. C., Kim, H., Salcedo, E., Yonchek, J. C., Rodgers, K. M., Orfila, J. E., et al. (2018). Endogenous sex steroids dampen neuroinflammation and improve outcome of traumatic brain injury in mice. J. Mol. Neurosci. 64, 410-420. doi: 10.1007/s12031-018-1038-x
Coleman, E., Bockting, W., Botzer, M., Cohen-Kettenis, P., DeCuypere, G., Feldman, J., et al. (2012). Standards of care for the health of transsexual, transgender, and gender-nonconforming people, version 7. Int. J. Transgenderism 13, 165-232. doi: 10.1080/15532739.2011.700873

Cook, S., Hung, V., and Duncan, KA. (2020). Crosstalk between estrogen withdrawal and $\mathrm{NF \kappa B}$ signaling following penetrating brain injury. Neuroimmunomodulation 25, 193-200. doi: 10.1159/000493506

Corre, C., Friedel, M., Vousden, D. A., Metcalf, A., Spring, S., Qiu, L. R., et al. (2016). Separate effects of sex hormones and sex chromosomes on brain structure and function revealed by high-resolution magnetic resonance imaging and spatial navigation assessment of the Four Core Genotype mouse model. Brain Struct. Funct. 221, 997-1016. doi: 10.1007/s00429-014-0952-0

Corrigan, J. D., Selassie, A. W., and Orman, J. A. (2010). The epidemiology of traumatic brain injury. J. Head Trauma Rehabil. 25, 72-80. doi: 10.1097/HTR.0b013e3181ccc8b4

Day, N. L., Floyd, C. L., D’Alessandro, T. L., Hubbard, W. J., and Chaudry, I. H. (2013). 17ß-estradiol confers protection after traumatic brain injury in the rat and involves activation of $\mathrm{G}$ protein-coupled estrogen receptor $1 . \mathrm{J}$. Neurotrauma 30, 1531-1541. doi: 10.1089/neu.2013.2854

Defreyne, J., and T'Sjoen, G. (2019). Transmasculine hormone therapy. Endocrinol. Metab. Clin. North Am. 48, 357-375. doi: 10.1016/j.ecl.2019.01.004

Deutsch, M. B., Bhakri, V., and Kubicek, K. (2015). Effects of cross-sex hormone treatment on transgender women and men. Obstet. Gynecol. 125, 605-610. doi: 10.1097/AOG.0000000000000692

Dickey, L. M., and Singh, A. A. (2017). Finding a trans-affirmative provider: challenges faced by trans and gender diverse psychologists and psychology trainees. J. Clin. Psychol. 73, 938-944. doi: 10.1002/jclp.22508

Du, L., Bayir, H., Lai, Y., Zhang, X., Kochanek, P. M., Watkins, S. C., et al. (2004). Innate gender-based proclivity in response to cytotoxicity and programmed cell death pathway. J. Biol. Chem. 279, 38563-38570. doi: 10.1074/jbc.M4054 61200

Dubal, D. B., Rau, S. W., Shughrue, P. J., Zhu, H., Yu, J., Cashion, A. B., et al. (2006). Differential modulation of estrogen receptors. (ERs) in ischemic brain injury: a role for ERalpha in estradiol-mediated protection against delayed cell death. Endocrinology 147, 3076-3084. doi: 10.1210/en.2005-1177

Dubal, D. B., and Wise, P. M. (2002). Estrogen and neuroprotection: from clinical observations to molecular mechanisms. Dialogues Clin. Neurosci. 4, 149-162. doi: 10.31887/DCNS.2002.4.2/ddubal

Duncan, K. A. (2020). Estrogen formation and inactivation following TBI: what we know and where we could go. Front. Endocrinol. 11:345. doi: $10.3389 /$ fendo.2020.00345

Duncan, K. A., and Saldanha, C. J. (2013). Inducible Aromatase in Astroglia: Protection and Recovery From Neural Perturbation in Birds. Oxford: Oxford University Press. doi: 10.1093/acprof:oso/9780199841196.003.0020

Duncan, K. A., and Saldanha, C. J. (2020). Central aromatization: a dramatic and responsive defense against threat and trauma to the vertebrate brain. Front. Neuroendocrinol. 56:100816. doi: 10.1016/j.yfrne.2019.100816

Duncan, K. A., and Saldanha, C. J. J. (2011). Neuroinflammation induces glial aromatase expression in the uninjured songbird brain. J. Neuroinflammation. 8:81. doi: 10.1186/1742-2094-8-81

Feldman, J., and Safer, J. (2009). Hormone therapy in adults: suggested revisions to the sixth version of the standards of care. Int. J. Transgenderism. 11, 146-182. doi: 10.1080/15532730903383757

Fernández, R., Cortés-Cortés, J., Esteva, I., Gómez-Gil, E., Almaraz, M. C., Lema, E., et al. (2015). The CYP17 MspA1 polymorphism and the gender dysphoria. J. Sex Med. 12, 1329-1333. doi: 10.1111/jsm.12895

Fernández, R., Guillamon, A., Cortés-Cortés, J., Gómez-Gil, E., Jácome, A., Esteva, I., et al. (2018). Molecular basis of Gender Dysphoria: androgen and estrogen receptor interaction. Psychoneuroendocrinology 98, 161-167. doi: 10.1016/j.psyneuen.2018.07.032

Fisher, A. D., Ristori, J., Morelli, G., and Maggi, M. (2018). The molecular mechanisms of sexual orientation and gender identity. Mol. Cell. Endocrinol. 467, 3-13. doi: 10.1016/j.mce.2017.08.008

Fitch, M. T., Doller, C., Combs, C. K., Landreth, G. E., and Silver, J. (1999). Cellular and molecular mechanisms of glial scarring and progressive cavitation: in vivo and in vitro analysis of inflammationinduced secondary injury after CNS trauma. J. Neurosci. 19, 8182-8198. doi: 10.1523/JNEUROSCI.19-19-08182.1999 
Foreman, M., Hare, L., York, K., Balakrishnan, K., Sánchez, F. J., Harte, F., et al. (2019). Genetic link between gender dysphoria and sex hormone signaling. J. Clin. Endocrinol. Metab. 104, 390-396. doi: 10.1210/jc.2018-01105

Funabashi, T., Sakakibara, H., Hirahara, F., and Kimura, F. (2018). Reduced luteinizing hormone induction following estrogen and progesterone priming in female-to-male transsexuals. Front. Endocrinol. 9:212. doi: $10.3389 /$ fendo.2018.00212

Garcia-Segura, L. M., Veiga, S., Sierra, A., Melcangi, R. C., and Azcoitia, I. (2003). Aromatase: a neuroprotective enzyme. Prog. Neurobiol. 71, 31-41. doi: 10.1016/j.pneurobio.2003.09.005

Giordano, K. R., Rojas-Valencia, L. M., Bhargava, V., and Lifshitz, J. (2020). Beyond binary: influence of sex and gender on outcome after traumatic brain injury. $J$ Neurotrauma 37, 2454-2459. doi: 10.1089/neu.2020.7230

Gölz, C., Kirchhoff, F. P., Westerhorstmann, J., Schmidt, M., Hirnet, T., Rune, G. M., et al. (2019). Sex hormones modulate pathogenic processes in experimental traumatic brain injury. J. Neurochem. 150, 173-187. doi: 10.1111/jnc.14678

Griesbach, G. S., Kreber, L. A., Harrington, D., and Ashley, M. J. (2015). Post-acute traumatic brain injury rehabilitation: effects on outcome measures and life care costs. J. Neurotrauma 32, 704-711. doi: 10.1089/neu.2014.3754

Gupte, R., Brooks, W. M., Vukas, R. R., Pierce, J. D., and Harris, J. L. (2019). Sex differences in traumatic brain injury: what we know and what we should know. J. Neurotrauma 36, 3063-3091. doi: 10.1089/neu.2018.6171

Hall, E. D., Gibson, T. R., and Pavel, K. M. (2005). Lack of a gender difference in post-traumatic neurodegeneration in the mouse controlled cortical impact injury model. J. Neurotrauma 22, 669-679. doi: 10.1089/neu.2005.22.669

Hamidi, O., and Davidge-Pitts, C. J. (2019). Transfeminine hormone therapy. Endocrinol. Metab. Clin. North Am. 48, 341-355. doi: 10.1016/j.ecl.2019.02.001

Hembree, W. C., Cohen-Kettenis, P., Delemarre-van de Waal, H. A., Gooren, L. J., Meyer, W. J., Spack, N. P., et al. (2009). Endocrine treatment of transsexual persons:an endocrine society clinical practice guideline. J. Clin Endocrinol. Metab. 94, 3132-3154. doi: 10.1210/jc.2009-0345

Hembree, W. C., Cohen-Kettenis, P. T., Gooren, L., Hannema, S. E., Meyer, W. J., Murad, M. H., et al. (2017). Endocrine treatment of gender-dysphoric/ genderincongruent persons: An endocrine society*clinical practice guideline. J. Clin. Endocrinol. Metab. 102, 3869-3903. doi: 10.1210/jc.2017-01658

Herson, P. S., Koerner, I. P., and Hurn, P. D. (2009). Sex, sex steroids, and brain injury. Semin. Reprod. Med. 27, 229-239. doi: 10.1055/s-0029-1216276

Hutson, C. B., Lazo, C. R., Mortazavi, F., Giza, C. C., Hovda, D., and Chesselet, M. F. (2011). Traumatic brain injury in adult rats causes progressive nigrostriatal dopaminergic cell loss and enhanced vulnerability to the pesticide paraquat. J. Neurotrauma 28, 1783-1801. doi: 10.1089/neu.2010.1723

Jauk, D. (2013). Gender violence revisited: lessons from violent victimization of transgender identified individuals. Sexualities 16, 807-825. doi: $10.1177 / 1363460713497215$

Joel, D., and McCarthy, M. M. (2017). Incorporating sex as a biological variable in neuropsychiatric research: where are we now and where should we be? Neuropsychopharmacology 42, 1-7. doi: 10.1038/npp.2016.79

Kim, H., Cam-Etoz, B., Zhai, G., Hubbard, W. J., Zinn, K. R., and Chaudry, I. H. (2015). Salutary effects of estrogen sulfate for traumatic brain injury. J. Neurotrauma 32, 1210-1216. doi: 10.1089/neu.2014.3771

Korse, C. M., Bonfrer, J. M. G., Van Beurden, M., Verheijen, R. H. M., and Rookus, M. A. (2009). Estradiol and testosterone levels are lower after oophorectomy than after natural menopause. Tumor. Biol. 30, 37-42. doi: 10.1159/000199449

Kurth, F., Luders, E., Sicotte, N. L., Gaser, C., Giesser, B. S., Swerdloff, R. S., et al. (2014). Neuroprotective effects of testosterone treatment in men with multiple sclerosis. Neuro Image Clin. 4, 454-460. doi: 10.1016/j.nicl.2014.03.001

Lenzlinger, P. M., Morganti-Kossmann, M. C., Laurer, H. L., and McIntosh, T. K. (2001). The duality of the inflammatory response to traumatic brain injury. Mol. Neurobiol. 24, 169-181. doi: 10.1385/MN:24:1-3:169

Ley, E. J., Short, S. S., Liou, D. Z., Singer, M. B., Mirocha, J., Melo, N., et al. (2013). Gender impacts mortality after traumatic brain injury in teenagers. J. Trauma Acute Care Surg. 75, 682-686. doi: 10.1097/TA.0b013e31829d024f

Lippa, R., and Hershberger, S. (1999). Genetic and environmental influences on individual differences in masculinity, femininity, and gender diagnosticity: analyzing data from a classic twin study. J. Pers. 67, 127-155. doi: 10.1111/1467-6494.00050

Lu, X. Y., Sun, H., Li, Q. Y., and Lu, P. S. (2016). Progesterone for traumatic brain injury: a meta-analysis review of randomized controlled trials. World Neurosurg. 90, 199-210. doi: 10.1016/j.wneu.2016. 02.110

Lye, T. C., and Shores, E. A. (2000). Traumatic brain injury as a risk factor for Alzheimer's disease: a review. Neuropsychol. Rev. 10, 115-129. doi: 10.1023/A:1009068804787

Ma, C., Wu, X., Shen, X., Yang, Y., Chen, Z., Sun, X., et al. (2019). Sex differences in traumatic brain injury: a multi-dimensional exploration in genes, hormones, cells, individuals, and society. Chin. Neurosurg. J. 5, 1-9. doi: 10.1186/s41016-019-0173-8

Maas, A. I., Stocchetti, N., and Bullock, R. (2008). Moderate and severe traumatic brain injury in adults. Lancet Neurol. 7, 728-741. doi: 10.1016/S1474-4422(08)70164-9

Manwani, B., Bentivegna, K., Benashski, S. E., Venna, V. R., Xu, Y., Arnold, A. P., et al. (2015). Sex differences in ischemic stroke sensitivity are influenced by gonadal hormones, not by sex chromosome complement. J. Cereb. Blood Flow Metab. 35, 221-229. doi: 10.1038/jcbfm.2014.186

McCullough, L. D., Mirza, M. A., Xu, Y., Bentivegna, K., Steffens, E. B., Ritzel, R., et al. (2016). Stroke sensitivity in the aged: Sex chromosome complement vs. gonadal hormones. Aging 8, 1432-1441. doi: 10.18632/aging. 100997

McKee, A. C., Cantu, R. C., Nowinski, C. J., Hedley-Whyte, E. T., Gavett, B. E., Budson, A. E., et al. (2009). Chronic traumatic encephalopathy in athletes: progressive tauopathy after repetitive head injury. J Neuropathol. Exp. Neurol. 68, 709-735. doi: 10.1097/NEN.0b013e3181a9d503

Menvielle, E., and Gomez-Lobo, V. (2011). Management of children and adolescents with gender dysphoria. J. Pediatr. Adolesc. Gynecol. 24, 183-188. doi: 10.1016/j.jpag.2010.12.006

Mikolić, A., van Klaveren, D., Oude Groeniger, J., Wiegers, E. J. A., Lingsma, H. F., Zeldovich, M., et al. (2020). Differences between men and women in treatment and outcome after traumatic brain injury. J. Neurotrauma 38, 235-251.doi: 10.1089/neu.2020.7228

Mollayeva, T., Mollayeva, S., and Colantonio, A. (2018). Traumatic brain injury: sex, gender and intersecting vulnerabilities. Nat. Rev. Neurol. 14, 711-722. doi: 10.1038/s41582-018-0091-y

Neblett, M. F., and Hipp, H. S. (2019). Fertility considerations in transgender persons. Endocrinol. Metab. Clin. North Am. 48, 391-402. doi: 10.1016/j.ecl.2019.02.003

Nguyen, H. B., Chavez, A. M., Lipner, E., Hantsoo, L., Kornfield, S. L., Davies, R. D., et al. (2018). Gender-affirming hormone use in transgender individuals: impact on behavioral health and cognition. Curr. Psychiatry Rep. 20:110. doi: 10.1007/s11920-018-0973-0

Niemeier, J. P., Marwitz, J. H., Walker, W. C., Davis, L. C., Bushnik, T., Ripley, D. L., et al. (2013). Are there cognitive and neurobehavioural correlates of hormonal neuroprotection for women after TBI? Neuropsychol. Rehabil. 23, 363-382. doi: 10.1080/09602011.2012.761944

Olson, K. R. (2016). Prepubescent transgender children: what we do and do not know. J. Am. Acad. Child Adolesc. Psychiatry. 55, 155-156.e3. doi: 10.1016/j.jaac.2015.11.015

Orozco, L. J., Tristan, M., Vreugdenhil, M. M. T., and Salazar, A. (2014). Hysterectomy versus hysterectomy plus oophorectomy for premenopausal women. Cochrane Database Syst. Rev. 2014:CD005638. doi: 10.1002/14651858.CD005638.pub3

Ortiz, J. B., Sukhina, A., Balkan, B., Harootunian, G., Adelson, P. D., Lewis, K. S., et al. (2020). Epidemiology of pediatric traumatic brain injury and hypothalamic-pituitary disorders in arizona. Front. Neurol. 10:1410. doi: 10.3389/fneur.2019.01410

Pedersen, A. L., Brownrout, J. L., and Saldanha, C. J. (2018). Neuroinflammation and neurosteroidogenesis: Reciprocal modulation during injury to the adult zebra finch brain. Physiol. Behav. 187, 51-56. doi: 10.1016/j.physbeh.2017.10.013

Perera, H. K., Ananth, C V., Richards, C. A., Neugut, A. I., Lewin, S. N., Lu, Y. S., et al. (2013). Variation in ovarian conservation in women undergoing hysterectomy for benign indications. Obstet. Gynecol. 121, 717-726. doi: 10.1097/AOG.0b013e3182887a47

Polderman, T. J. C., Kreukels, B. P. C., Irwig, M. S., Beach, L., Chan, Y. M., Derks, E. M., et al. (2018). The biological contributions to gender identity and gender diversity: bringing data to the table. Behav. Genet. 48, 95-108. doi: $10.1007 / \mathrm{s} 10519-018-9889-\mathrm{z}$ 
Porter, K. E., Brennan-Ing, M., Chang, S. C., Dickey L. M., Singh, A. A., Bower, K. L., et al. (2016). Providing competent and affirming services for transgender and gender nonconforming older adults. Clin. Gerontol. 39, 366-388. doi: 10.1080/07317115.2016.1203383

Prins, M., Greco, T., Alexander, D., and Giza, C. C. (2013). The pathophysiology of traumatic brain injury at a glance. DMM Dis. Model. Mech. 6, 1307-1315. doi: $10.1242 / \mathrm{dmm} .011585$

Rahimian, R., Cordeau, P., and Kriz, J. (2019). Brain response to injuries: when microglia go sexist. Neuroscience 405, 14-23. doi: 10.1016/j.neuroscience.2018.02.048

Ranganathan, P., Kumar, R. G., Davis, K., McCullough, E. H., Berga, S. L., and Wagner, A. K. (2016). Longitudinal sex and stress hormone profiles among reproductive age and post-menopausal women after severe TBI: a case series analysis. Brain Inj. 30, 452-461. doi: 10.3109/02699052.2016.1144081

Reisner, S. L., Poteat, T., Keatley, J. A., Cabral, M., Mothopeng, T., Dunham, E., et al. (2016). Global health burden and needs of transgender populations: a review. Lancet 388, 412-436. doi: 10.1016/S0140-6736(16)00684-X

Ripley, D. L., Gerber, D., Pretz, C., Weintraub, A. H., and Wierman, M. E. (2020). Testosterone replacement in hypogonadal men during inpatient rehabilitation following traumatic brain injury: results from a doubleblind, placebo-controlled clinical pilot study. Neuro Rehabil. 46, 355-368. doi: 10.3233/NRE-192992

Rocca, W. A. (2017). Time, sex, gender, history, and dementia. Alzheimer Dis. Assoc. Disord. 31, 76-79. doi: 10.1097/WAD.0000000000000187

Rubin, T. G., and Lipton, M. L. (2019). Sex differences in animal models of traumatic brain injury. J. Exp. Neurosci. 13:117906951984402. doi: $10.1177 / 1179069519844020$

Safer, J. D., Coleman, E., Feldman, J., Garofalo, R., Hembree, W., Radix, A., et al. (2016). Barriers to healthcare for transgender individuals. Curr. Opin. Endocrinol. Diabetes Obes. 23, 168-171. doi: 10.1097/MED.0000000000000227

Saldanha, C. J., Burstein, S. R., and Duncan, K. A. (2013). Induced synthesis of estrogens by glia in the songbird brain. J. Neuroendocrinol. 25, 1032-1038.doi: 10.1111/jne.12067

Sanchez, N. F., Sanchez, J. P., and Danoff, A. (2009). Health care utilization, barriers to care, and hormone usage among male-to-female transgender persons in New York City. Am. J. Public Health. 99, 713-719. doi: 10.2105/AJPH.2007.132035

Slewa-Younan, S., Green, A. M., Baguley, I. J., Gurka, J. A., and Marosszeky, J. E. (2004). Sex differences in injury severity and outcome measures after traumatic brain injury. Arch. Phys. Med. Rehabil. 85, 376-379. doi: 10.1016/j.apmr.2003.05.007

Smith, E. S., Junger, J., Derntl, B., and Habel, U. (2015). The transsexual brain A review of findings on the neural basis of transsexualism. Neurosci. Biobehav. Rev. 59, 251-266. doi: 10.1016/j.neubiorev.2015.09.008

Smith, Y. L. S., Van Goozen, S. H. M., and Cohen-Kettenis, P. T. (2001). Adolescents with gender identity disorder who were accepted or rejected for sex reassignment surgery: a prospective follow-up study. J. Am. Acad. Child Adolesc. Psychiatry 40, 472-481. doi: 10.1097/00004583-200104000-00017

Späni, C. B., Braun, D. J., and Van Eldik, L. J. (2018). Sex-related responses after traumatic brain injury: considerations for preclinical modeling. Front. Neuroendocrinol. 50, 52-66. doi: 10.1016/j.yfrne.2018.03.006

Spence, R. D., and Voskuhl, R. R. (2012). Neuroprotective effects of estrogens and androgens in CNS inflammation and neurodegeneration. Front. Neuroendocr. 33, 105-115. doi: 10.1016/j.yfrne.2011.12.001

Stein, D. G. (2015). Embracing failure: what the phase III progesterone studies can teach about TBI clinical trials. Brain Inj. 29, 1259-1272. doi: 10.3109/02699052.2015.1065344
Stein, D. G., and Hoffman, S. W. (2003). Estrogen and progesterone as neuroprotective agents in the treatment of acute brain injuries. Pediatr. Rehabil. 6, 13-22. doi: 10.1080/1363849031000095279

Stein, D. G., Howard, R. B., and Sayeed, I. (2016). "Why did the phase III clinical trials for progesterone in TBI fail? An analysis of three potentially critical factors," in New Therapeutics for Traumatic Brain Injury: Prevention of Secondary Brain Damage and Enhancement of Repair and Regeneration, ed K. A. Heidenreich (Amsterdam: Elsevier Inc.), 3-18. doi: 10.1016/B978-0-12-802686-1.00001-8

Suzuki, S., Gerhold, L. M., Böttner, M., Rau, S. W., Dela Cruz, C., Yang, E., et al. (2007). Estradiol enhances neurogenesis following ischemic stroke through estrogen receptors $\alpha$ and $\beta$. J. Comp. Neurol. 500, 1064-1075. doi: $10.1002 / \mathrm{cne} .21240$

Szyf, M., McGowan, P., and Meaney, M. J. (2008). The social environment and the epigenome. Environ. Mol. Mutagen. 49, 46-60. doi: 10.1002/em.20357

The World Professional Association for Transgender Health (2012). Standards of Care for the Health of Transsexual, Transgender, and Gender-Nonconforming People. Available online at: www.wpath.org

Theisen, J. G., Sundaram, V., Filchak, M. S., Chorich, L. P., Sullivan, M. E., Knight, J., et al. (2019). The use of whole exome sequencing in a cohort of transgender individuals to identify rare genetic variants. Sci. Rep. 9, 1-11. doi: 10.1038/s41598-019-53500-y

T'Sjoen, G., Arcelus, J., Gooren, L., Klink, D. T., and Tangpricha, V. (2019). Endocrinology of transgender medicine. Endocr. Rev. 40, 97-117. doi: 10.1210/er.2018-00011

Unger, C. A. (2016). Hormone therapy for transgender patients. Transl. Androl. Urol. 5, 877-884. doi: 10.21037/tau.2016.09.04

Wiepjes, C. M., de Blok, C. J. M., Staphorsius, A. S., Nota, N. M., Vlot, M. C., de Jongh, R. T., et al. (2020). Fracture risk in trans women and trans men using long-term gender-affirming hormonal treatment: a nationwide cohort study. J. Bone Miner Res. 35, 64-70. doi: 10.1002/jbmr.3862

Wright, D. W., Kellermann, A. L., Hertzberg, V. S., Clark, P. L., Frankel, M., Goldstein, F. C., et al. (2007). ProTECT: a randomized clinical trial of progesterone for acute traumatic brain injury. Ann. Emerg. Med. 49, 391-402.e1-2. doi: 10.1016/j.annemergmed.2006.07.932

Wunderle, K., Hoeger, K. M., Wasserman, E., and Bazarian, J. J. (2014). Menstrual phase as predictor of outcome after mild traumatic brain injury in women. $J$. Head Trauma Rehabil. 29, E1-E8. doi: 10.1097/HTR.0000000000000006

Yang, F., Zhu, X. H., Zhang, Q., Sun, N. X., Ji, Y. X., Ma, J. Z., et al. (2017). Genomic characteristics of gender dysphoria patients and identification of rare mutations in RYR3 gene. Sci. Rep. 7, 1-9. doi: 10.1038/s41598-017-08655-x

Yeung, H., Kahn, B., Ly, B. C., and Tangpricha, V. (2019). Dermatologic conditions in transgender populations. Endocrinol. Metab. Clin. North Am. 48, 429-440. doi: 10.1016/j.ecl.2019. 01.005

Conflict of Interest: The authors declare that the research was conducted in the absence of any commercial or financial relationships that could be construed as a potential conflict of interest.

Copyright (c) 2021 Duncan and Garijo-Garde. This is an open-access article distributed under the terms of the Creative Commons Attribution License (CC BY). The use, distribution or reproduction in other forums is permitted, provided the original author(s) and the copyright owner(s) are credited and that the original publication in this journal is cited, in accordance with accepted academic practice. No use, distribution or reproduction is permitted which does not comply with these terms. 